\title{
22. RIFTING OF THE TONGA/LAU RIDGE AND FORMATION OF THE LAU BACKARC BASIN: EVIDENCE FROM SITE 840 ON THE TONGA RIDGE ${ }^{1}$
}

\author{
D.R. Tappin, ${ }^{2}$ T.R. Bruns, ${ }^{3}$ and E.L. Geist ${ }^{3}$
}

\begin{abstract}
The tectono-sedimentary evolution of the southern Tonga Ridge during the latest Miocene to Pleistocene is described from seismic reflection profiles and drilling results from Site 840 , located on the western margin of the Tonga Ridge. The evolution took place in three episodes that have been related to the rifting of the Tonga/Lau Ridge and spreading in the Lau Basin. Uplift of the Tonga Ridge in the latest Miocene is attributed to deformation caused by the rifting of the Tonga/Lau Ridge. The uplift confined sedimentation to the western side of the Tonga Ridge, although the (mainly volcanic) sediment sources remained unchanged from the Lau Ridge. A phase of minor flexuring and faulting in the early Pliocene precedes a period of effusive volcanism, during which depositional limits expanded. The volcanic source was again from the Lau Ridge, and the volcanism is interpreted as taking place during a final rifting phase before the sundering of the Tonga/Lau Ridge. A further phase of minor flexuring in the early Pliocene is attributed to the sundering of the Tonga/Lau Ridge. Subsequent deposition on the Tonga Ridge takes place in isolation from the Lau Ridge. Late Pliocene volcanic sediments are sourced from the Tofua Arc, newly formed on the western margin of the Tonga Ridge.
\end{abstract}

\section{INTRODUCTION}

Site 840 (Fig. 1; Parson et al., 1992), located on the western side of the southern Tonga Ridge, was drilled to investigate the timing of the regional tectonic events that have affected the Tonga (and Lau) Ridge(s) before and during the formation of the Lau Basin. Specific objectives at the site were to date seismic sequences SB-A (sea bottom to Horizon A) and A-B of Herzer and Exon (1985) and the unconformity represented by Horizon A. Sequences SB-A and A-B were originally identified on the L5-82-SP multichannel seismic reflection data (Herzer and Exon, 1985; Scholl and Vallier, 1985) and have been traced across much of the southern Tonga Ridge (Herzer and Exon, 1985; Tappin et al., 1994).

Until Site 840 was drilled during Ocean Drilling Program (ODP) Leg 135, the stratigraphy of the southern part of the Tonga Ridge (Tappin, 1993, and references therein) had been based mainly upon a regional cover of multichannel seismic reflection data and dredge sampling (Scholl and Vallier, 1985; Stevenson et al., 1994). Four seismostratigraphic sequences, the uppermost of which is Sequence SB-A, can be identified within the sedimentary basin that occupies the ridge summit. Horizon A is considered to be of either early Pliocene (Chaproniere, 1985; Exon et al., 1985; Herzer and Exon, 1985) or late Pliocene (Tappin et al., 1994) age. The nature of the unconformity varies, being marked by significant onlap in some areas and by paraconformity in others. Sequence A-B is considered to comprise late Miocene to early Pliocene volcaniclastic sediments sourced from the Lau Ridge (Scholl and Vallier, 1985). Sequence SB-A is considered to comprise Pliocene to Quaternary calcareous ooze together with derived and vitric volcanic sediment (Scholl and Vallier, 1985). The source of the volcanic sediment has been interpreted as coming from the Tofua volcanic arc, which is located on the western flank of the Tonga Ridge (Fig. 1).

Horizon A previously was interpreted as having been formed during the rifting of the Tonga/Lau Ridge (Herzer and Exon, 1985; Scholl et al., 1985). The early to late Pliocene age of the unconformity was coeval with the age of initiation of Lau Basin formation, which

\footnotetext{
${ }^{1}$ Hawkins, J., Parson, L., Allan, J., et al., 1994. Proc, ODP, Sci. Results, 135: College Station, TX (Ocean Drilling Program).

${ }^{2}$ British Geological Survey, Keyworth, Nottingham, NG12 5GG, United Kingdom.

${ }^{3}$ Branch of Pacific Marine Geology, U.S. Geological Survey, M.S. 999. 345 Middlefield Road, Menlo Park, CA 94025 , U.S.A.
}

is generally agreed to have taken place during the early Pliocene (Malahoff et al., 1982; Weissel, 1977). The Sequence A-B sediments were considered to have been laid down when the Lau and Tonga ridges formed a composite arc structure, whereas the Sequence SB-A sediments were considered to have been deposited after the rifting of the Tonga/Lau Ridge and during the post-rift spreading in the Lau (backarc) Basin (Herzer and Exon, 1985). As the Lau Basin opened, the Tonga Ridge was progressively transported eastward.

The proposed evolution of the Tonga Ridge and Lau Basin outlined above was revised when a new interpretation of residual magnetic anomaly lineations was published by Parson et al. (1990). The interpretation showed that the sundering of the Tonga/Lau Ridge was initiated in the latest Miocene (5-6 Ma), an age that had previously been proposed by Cherkis (1980).

\section{DRILLING RESULTS}

Three sedimentary units were penetrated at Site 840 (Parson, Hawkins, Allan, et al., 1992).

Unit III (260.5-597.3 mbsf) comprises an upward-fining sequence of late Miocene (6.6-5.3 Ma) volcaniclastic turbidites and nannofossil chalk, with volcaniclastic breccia and conglomerate in the lower parts. The Horizon A unconformity lies at $400-420$ mbsf within Unit III, approximately at the boundary of foraminifer Subzones 17A and 17B (Chaproniere, this volume). It is not marked by any major biostratigraphic, lithostratigraphic, or structural change. However, near or extending through the level of Horizon A, at a depth of $383 \mathrm{mbsf}$, a change takes place in the physical properties of the sediments and there is a zone of alteration (between 367 and $410 \mathrm{mbsf}$ ).

Unit II (109.98-260.5 mbsf) overlies Unit III without any stratigraphic break. It comprises earliest Pliocene (5.3-5.1 Ma) nannofossil chalk and vitric sandstone and siltstone and pumiceous gravel. Gravel and sandstone dominate the lower part of the unit below 124 mbsf, with bioturbated chalk comprising the upper part of the Unit.

Unit I (0-109.98 mbsf) comprises vitric nannofossil ooze, vitric silt, and vitric sand that are late Pliocene to Pleistocene in age. The initial biostratigraphic dating (Parson, Hawkins, Allan, et al., 1992) identified no hiatus between Units II and I, although an early Pliocene break was reported higher in Unit I at a depth of approximately 95-101 mbsf. However, Chaproniere (this volume) now suggests that the early Pliocene hiatus may indeed correlate with the lithologic break. Foraminifer evidence suggests that the hiatus spans most of 


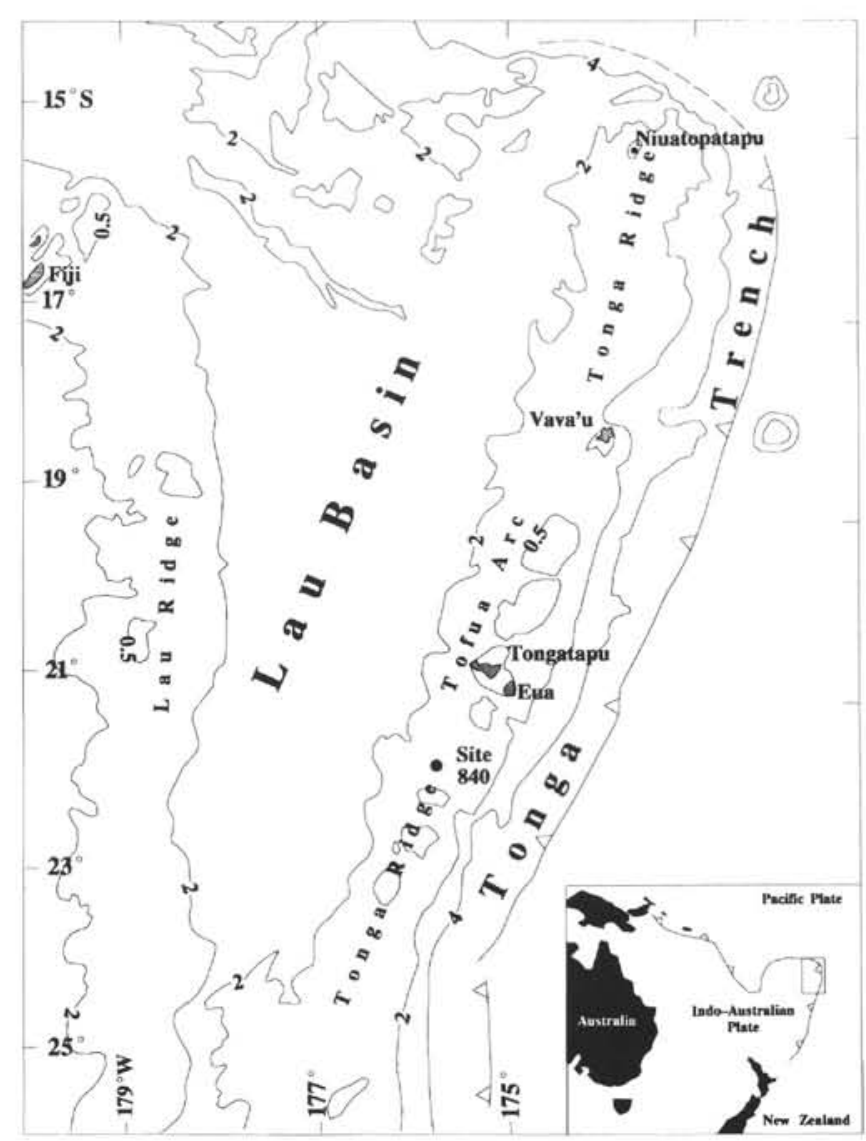

Figure 1. Location of Site 840 on the south Tonga Ridge.

Zone N19/20 (5.1-3.5 Ma; Chaproniere, this volume). Nannofossil evidence suggests that the hiatus spans the interval from Subzones $\mathrm{CN} 10 \mathrm{c}$ to CN11b (4.5-3.5 Ma; Quinterno, this volume).

\section{SEISMIC CORRELATION}

To correlate between the sedimentary sequence at Site 840 and multichannel seismic reflection data recorded over the site, a synthetic seismogram has been constructed from the velocity and density logs recorded at the site (Bruns et al., this volume). The seismic reflection data were acquired during the L5-82-SP cruise (Scholl and Vallier, 1985); line 14 crosses the site location and line 8 intersects line 142.5 $\mathrm{km}$ to the north-northeast (Figs. 2-4). Poor correlation exists between the reflections on the synthetic seismogram and the sedimentary unit boundaries. However, good correlations can be determined between the synthetic seismogram and Horizon A and between the synthetic seismogram and the seismic reflection data.

On multichannel seismic reflection line 14 (Fig. 3) at the location of Site 840 , no observable seismic disconformity can be found at the level of Horizon A, which lies above a doublet of moderate amplitude reflections. It may be traced northward along line 14 onto line 8 (Fig. 4) where, at the intersection of the two lines, a conformable sequence can be discerned. Traced eastward along line 8 , toward the Tonga Ridge crest, reflections onlap Horizon A. Horizon A, therefore, becomes an unconformity, the magnitude of which increases eastward and attains maximum expression on the ridge crest (not seen on Fig. 4).

Below Horizon A, Unit III is the uppermost part of a conformable seismic sequence (A-B) that thins eastward toward the ridge crest. Above the horizon, the seismic sequence also thins toward the ridge crest as reflections onlap updip onto Horizon A. To the east of shotpoint 1010, the reflection marking the upper boundary of Unit III

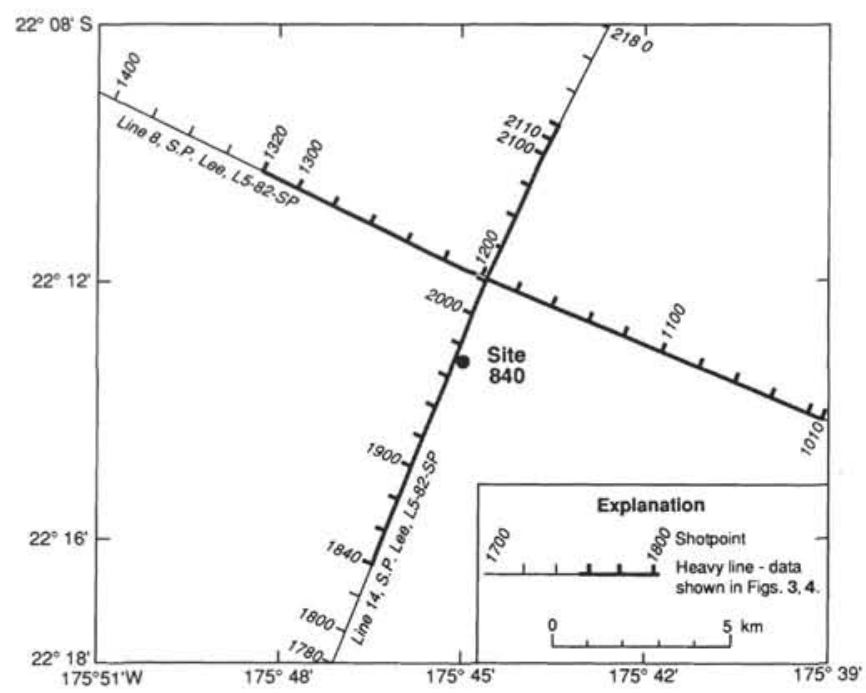

Figure 2. Location of S.P. Lee multichannel seismic lines 8 and 14 across Site 840 (Scholl and Vallier, 1985).

onlaps Horizon A. Site 840, therefore, penetrated a seismically continuous sequence to the west of the ridge crest that is the lateral equivalent of the Horizon A unconformity on the ridge crest.

The boundary between Units III and II on line 14 correlates with an intra-Sequence SB-A disconformity. Faults with minor throws displace reflections below the disconformity. A high-amplitude doublet below the disconformity correlates with the nannofossil chalks that predominate in the upper $60 \mathrm{~m}$ of Unit III. It can be traced onto line 8, where reflections within Unit II are subhorizontal. Within the lower part of Unit II, a series of moderate- to high-amplitude reflections are produced by the coarse pumiceous gravels. On line 8 , Unit II thins toward the ridge crest as reflections successively onlap updip onto Unit III and overstep onto Horizon A. Westward-dipping reflections are present at the eastern end of this line, and a minor unconformity (see common depth points 1280-1320 in Fig. 4) can be observed within the unit.

The boundary between Units II and I is at a shallow depth on the seismic profiles (at about $0.125 \mathrm{~s}$ below seafloor). It lies above the depth at which the geophysical logs were run at Site 840; therefore, the synthetic seismogram is not available for correlating Site 840 with the seismic profiles. Interpretation at such shallow depth on line 14 is also problematic because of intense faulting. However, a reflection of moderate amplitude correlates with the lithologic break at Site 840 at 109.98 mbsf, which has been picked as the boundary between Units II and I. On line 14 this boundary is a minor disconformity that can only be confidently identified in the vicinity of Site 840 . For the most part, reflections within Unit I are conformable with those immediately underlying in Unit II. On line 8, Unit I decreases in thickness toward the ridge crest (Fig. 4). Although one cannot see it very well on lines 8 and 14, the upper reflections of Sequence SB-A are truncated at the seabed.

\section{INTERPRETATION AND DISCUSSION}

The results of drilling at Site 840 (Parson, Hawkins, Allan, et al., 1992) warrant a revision of the previous interpretation of Horizon A and Sequence SB-A.

The seismic sequence (A-B) underlying Horizon A, the upper part of which was sampled at Site 840 , has now been proven to be at least of late Miocene age. It forms a westward-thickening sedimentary wedge, sourced from the west, that can be traced over much of the Tonga Ridge (Herzer and Exon, 1985; Tappin et al., 1994).

Although an apparently conformable sedimentary sequence was penetrated at Site 840 , the seismic evidence shows that Horizon A at 


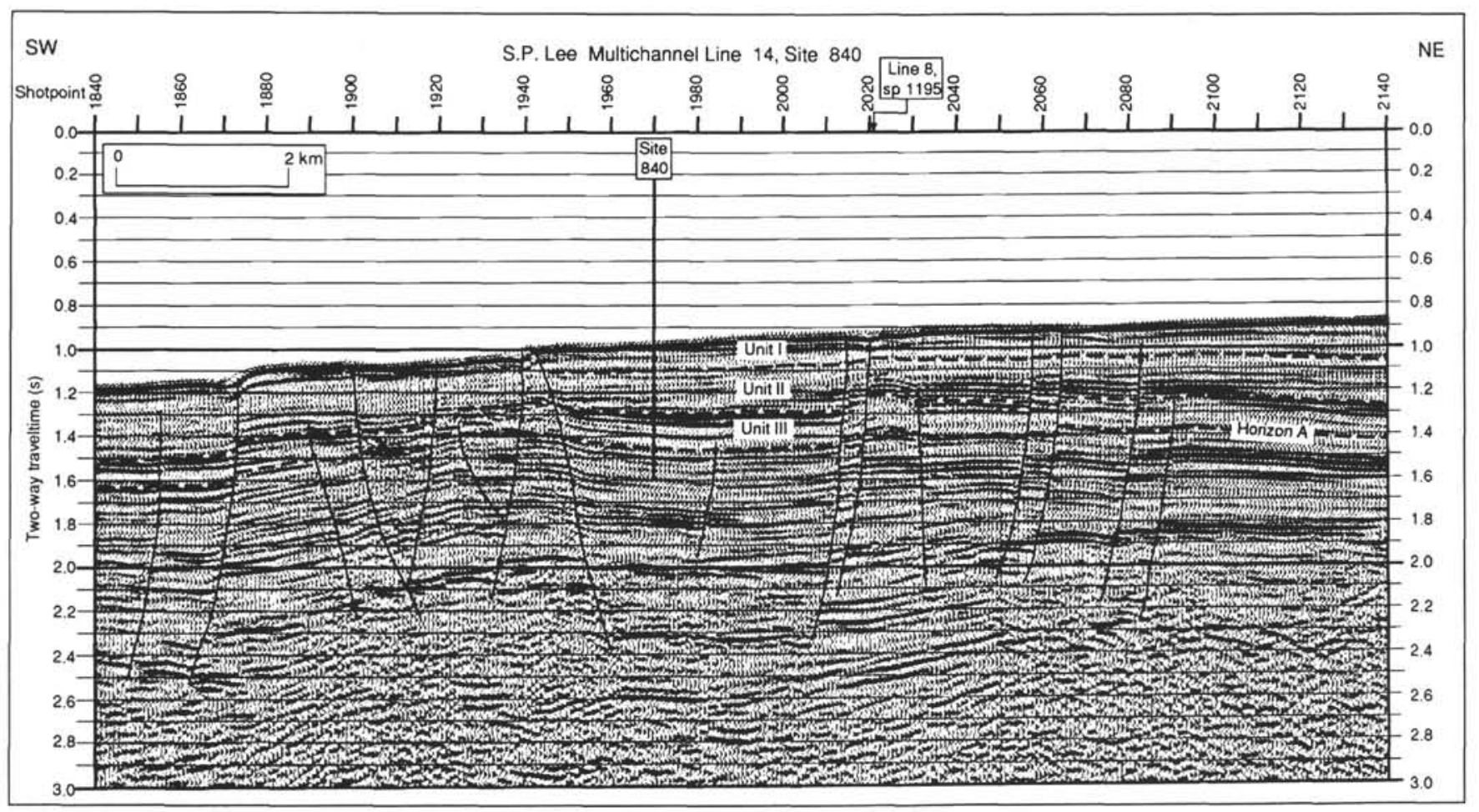

Figure 3. Multichannel seismic line 14 with interpretation showing lithologic Units I, II, and III penetrated at Site 840 (location also shown) and Horizon A. Line location shown on Figure 2.

this location is a paraconformity. The horizon, traced eastward on line 8 , becomes an unconformity that formed during the uplift of the ridge crest. The uplift must have taken place rapidly as no datable biostratigraphic break is present at the level of Horizon A. Although Horizon A was previously considered to be of Pliocene age, it has now been proven to be of latest Miocene age, the uplift taking place at about 5.8 Ma. The absence of any truncation of the reflections underlying Horizon A indicates either little or no erosion along line 8 or that the uplifted strata remained subhorizontal. Scholl et al. (1985) suggest that during the formation of Horizon A subaerial exposure of parts of the ridge crest may have taken place. Significant in this respect is the physical properties change and zone of alteration at the level of Horizon A at Site 840 (Parson, Hawkins, Allan, et al., 1992). Although there is no evidence to suggest subaerial exposure (reddening, presence of iron oxides, etc.), the intense cementation caused by authigenic mineralization at this level suggests a hiatus in deposition.

The latest Miocene uplift of the ridge crest confined post-Horizon A sedimentation to the western side of the ridge where the upper part of Unit III was laid down. The uplift had no effect on the type of sedimentation as volcanic turbidites and chalk continued to be deposited. Seismic relationships (eastward onlap) confirm that sediment sources continued to be to the west on the Lau Ridge as previously proposed (Parson, Hawkins, Allan, et al., 1992). However, the uplift correlates with a decrease in the sediment grain size and a reduction in the rate of sediment deposition (Parson, Hawkins, Allan, et al., 1992). The effects of uplift, therefore, were on basin geometry: source areas remained unchanged but became more distant.

The formation of Horizon A has been attributed to uplift associated with the sundering of the Tonga/Lau Ridge (Herzer and Exon, 1985; Scholl et al., 1985). We see no reason to change this interpretation except to point out that the uplift took place during the latest Miocene rather than in the Pliocene. The revised dating of Horizon A (latest Miocene) now correlates with the age of Tonga/Lau Ridge rifting proposed by Parson et al. (1990). The varying nature of Horizon A, unconformable in some areas and paraconformable in others, is attributed to differential uplift along and across the Tonga Ridge during the rifting event.

At the boundary between Units III and II, only minor flexuring and faulting can be observed.

Deposition of the lower part of Unit II continued to be confined by the ridge crest, which was still high-standing. The influx of the rapidly deposited, coarse volcanic sediment of Unit II mainly reflects a change to more proximal, (?subaerial) acidic volcanism. Volcanic sources were still to the west, on the Lau Ridge (Parson, Hawkins, Allan, et al., 1992). The overall sedimentary environment (water depths, circulation, etc.) was unchanged as bioturbated chalks continued to be laid down between volcanic episodes. During the later deposition of Unit II, sedimentation expanded over the ridge crest.

At the boundary between Units II and I, further minor flexuring occurs, although (again) major changes in sedimentation take place. Volcanic input declines, chalk is replaced by ooze, and sedimentation rates decline (Parson, Hawkins, Allan, et al., 1992). We consider the changes to be a result of the final separation (splitting) of the Tonga/Lau Ridge. The separation isolated the Tonga Ridge from Lau Ridge volcanic sources. The creation of a wider seaway increased the influence of more open circulation, leading to the chalk-ooze transition and lowered sedimentation rates. The hiatus within the oozes of lowermost Unit I may be a result of the lowering of the sea level during the lower Pliocene (Haq et al., 1988). In the context of the separation of the Lau and Tonga ridges, the volcanic sediments of Unit II are the last on the Tonga Ridge to be sourced in any volume from the Lau Ridge.

We regard the sedimentation of Unit I as taking place during the Lau Basin spreading. The dominance of calcareous oozes in the lowermost part of Unit I suggests that volcanic sources were distant or isolated by basin geometry. The pumiceous gravels, vitric volcanic sandstones, and siltstones in the upper part of Unit I indicate a resumption of more proximal volcanic deposition. We regard these volcanic sediments as sourced from the Tofua Arc, newly formed on the western margin of the Tonga Ridge. The initiation of volcanism at 3.5 $\mathrm{Ma}$ at Site 840 would be in general agreement with the only isotopic 


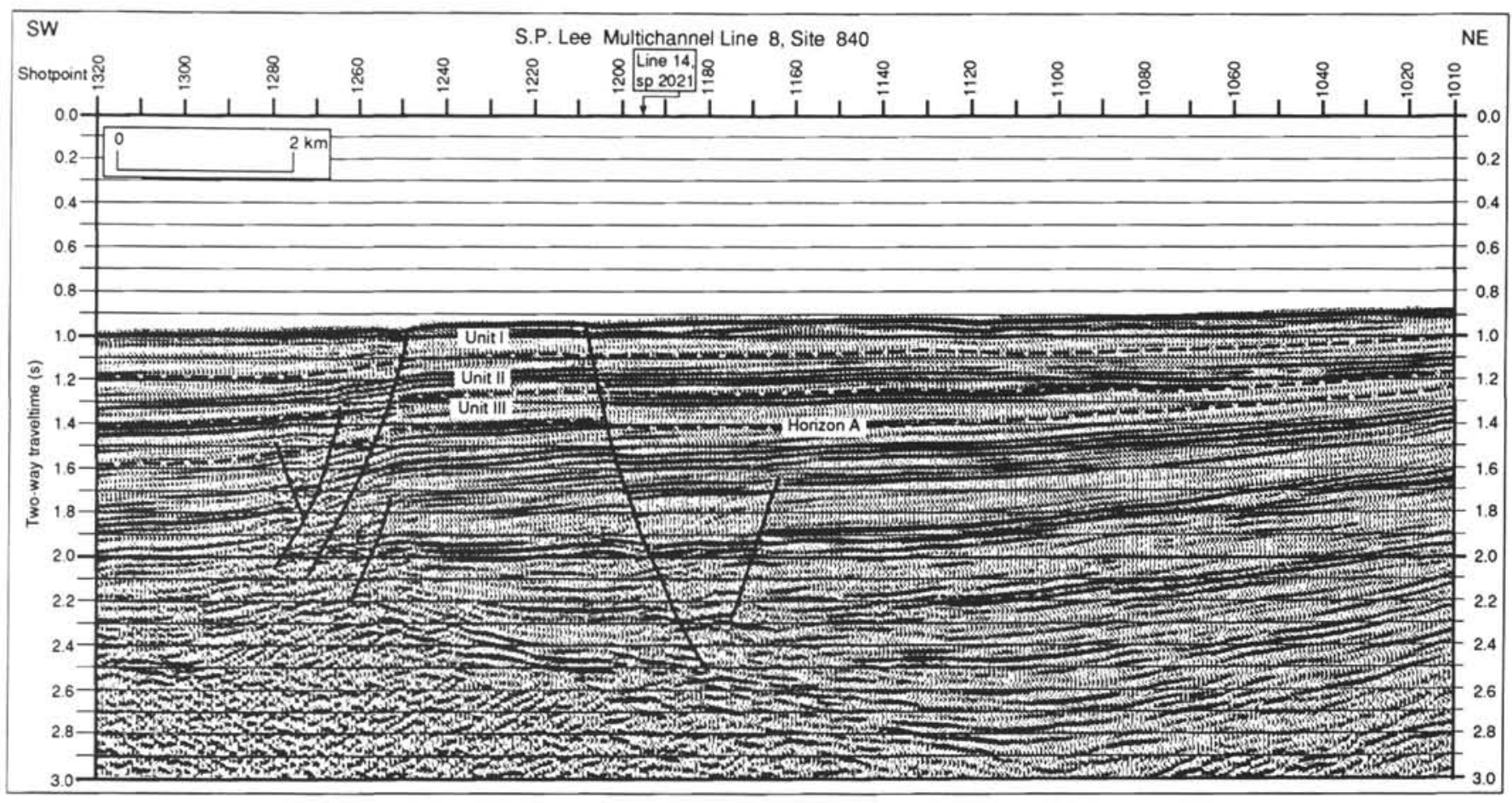

Figure 4. Multichannel seismic line 8 with interpretation of lithologic Units I, II, and III penetrated at Site 840 and Horizon A. Line location shown on Figure 2.

dating of the volcanic arc on Niuatopatapu at $3 \mathrm{Ma}(\mathrm{J}$. Gill, as cited in Tappin, 1993).

The thinning of Unit I toward the ridge crest, together with the truncation at the seabed of Unit I reflections, indicates post-Unit I uplift of the ridge crest to have taken place, as proposed by Scholl et al. (1985). The numerous faults on lines 8 and 14 formed at this time.

\section{SUMMARY}

The latest Miocene to Pleistocene evolution of the southern Tonga Ridge has been subdivided into three main episodes, based upon a correlation of multichannel seismic reflection profiles with the sedimentary sequence drilled at Site 840 . The episodes are related to rifting of the Tonga/Lau Ridge and spreading in the Lau Basin.

Uplift of the Tonga Ridge during the latest Miocene $(5.8 \mathrm{Ma})$ is attributed to the initial rifting of the Tonga/Lau Ridge. It led to the formation of a regional unconformity, Horizon A, and confined sedimentation to the west of the ridge crest. During uplift, volcanic sediment sources (from the Lau Ridge) remained unchanged, although they became more distal, and sedimentation rates declined.

Later evolution of the Tonga Ridge is marked by minor uplift and flexuring and an expansion of depositional limits eastward across the ridge crest. At the Miocene/Pliocene boundary, minor flexuring and faulting precedes early Pliocene effusive volcanicity. The volcanicity is considered to have taken place during the final stages of rifting of the Tonga/Lau Ridge.

Further minor flexuring precedes the deposition of late Pliocene ooze. Ooze deposition is interpreted as taking place during spreading in the Lau Basin when the Tonga and Lau ridges were finally separated. An early Pliocene hiatus may record lowered sea levels. Late Pliocene volcanic sediments were sourced from the newly formed Tofua volcanic arc, which lies on the western flank of the Tonga Ridge. Most recently, the Tonga Ridge has been elevated and eroded.

\section{ACKNOWLEDGMENTS}

This paper is published with the approval of the Director of the British Geological Survey (NERC). Reviews by R. Gatliff, D. Masson, and L.M. Parson improved this paper.

\section{REFERENCES $*$}

Chaproniere, G.C.H., 1985. Late Neogene and Quaternary planktonic foraminiferal biostratigraphy and paleobathymetry of dredge samples from the southern Tongan Platform (Cruise L5-82-SP). In Scholl, D.W., and Vallier, D.L. (Eds.), Geology and Offshore Resources of Pacific Island ArcsTonga Region. Circum-Pac. Counc. Energy Miner. Resour., Earth Sci. Ser., 2:131-140.

Cherkis, M.M., 1980. Aeromagnetic investigations and sea-floor spreading history in the Lau basin and northern Fiji Plateau. Symposium on Petroleum Potential in Island Arcs, Small Ocean Basins, Submerged Margins and Related Areas. Suva, Fiji, September 1979. U.N. ESCAP, CCOP/ SOPAC Tech. Bull., 3:37-46.

Exon, N.F., Herzer, R.H., and Cole, J., 1985. Mixed volcaniclastic and pelagic sedimentary rocks from the Cenozoic southern Tonga platform and their implications for petroleum potential. In Scholl, D.W., and Vallier, T.L. (Eds.), Geology and Offshore Resources of Pacific Island Arcs-Tonga Region. Circum-Pac. Counc. Energy Miner. Resour., Earth Sci. Ser., 2:75-107.

Haq, B.U., Hardenbol, J., and Vail, P.R., 1988. Mesozoic and Cenozoic chronostratigraphy and cycles of sea-level change. In Wilgus, C.K., Hastings, B.S., Kendall, C.G.St.C., Posamentier, H.W., Ross, C.A., and Van Wagoner, J.C. (Eds.), Sea-Level Changes-An Integrated Approach. Spec. Publ.-Soc. Econ. Paleontol. Mineral., 42:72-108.

\footnotetext{
Abbreviations for names of organizations and publication titles in ODP reference lists follow the style given in Chemical Abstracts Service Source Index (published by American Chemical Society).
} 
Herzer, R.H., and Exon, N.F., 1985. Structure and basin analysis of the southern Tonga forearc. In Scholl, D.W., and Vallier, T.L. (Eds.), Geology and Offshore Resources of Pacific Island Arcs-Tonga Region. CircumPac. Counc. Energy Miner. Resour., Earth Sci. Ser., 2:55-73.

Malahoff, A., Feden, R.H., and Fleming, H.S., 1982. Magnetic anomalies and tectonic fabric of marginal basins north of New Zealand. J. Geophys. Res., $87: 4109-4125$.

Parson, L., Hawkins, J., Allan, J., et al., 1992. Proc. ODP, Init. Repts., 135: College Station, TX (Ocean Drilling Program).

Parson, L.M., Pearce, J.A., Murton, B.J., Hodkinson, R.A., Bloomer, S., Ernewein, M., Huggett, Q.J., Miller, S., Johnson, L., Rodda, P., and Helu, S., 1990. Role of ridge jumps and ridge propagation in the tectonic evolution of the Lau back-arc basin, southwest Pacific. Geology, 18:470-473.

Scholl, D.W., and Vallier, T.L. (Eds.), 1985. Geology and Offshore Resources of Pacific Island Arcs-Tonga Region. Circum-Pac. Counc. Energy Miner. Resour., Earth Sci. Ser., 2.

Scholl, D.W., Vallier, T.L., and Packham, G.H., 1985. Framework geology and resource potential of the southern Tonga platform and adjacent terranes-a synthesis. In Scholl, D.W., and Vallier, T.L. (Eds.), Geology and Offshore Resources of Pacific Island Arcs-Tonga Region. Circum-Pac. Counc. Energy Miner. Resour., Earth Sci. Ser., 2:457-488.
Stevenson, A.J., Herzer, R.H., and Ballance, P.F. (Eds.), 1994. Marine and On-land Geology and Resource Assessment of the Tonga-Lau-Fiji Region. SOPAC Tech. Bull. 8.

Tappin, D.R., 1993. The Tonga frontal arc basin. In Ballance, P.F. (Ed.), Sedimentary Basins of the World: South Pacific Sedimentary Basins (Vol. 2): Amsterdam (Elsevier).

Tappin, D.R., Herzer, R.H., and Stevenson, A.J., 1994. Structure and stratigraphy of an oceanic forearc - the Tonga Ridge $-22^{\circ}-26^{\circ}$ South. In Stevenson, A.J., Herzer, R.H., and Ballance, P.F. (Eds.), Marine and On-land Geology and Resource Assessment of the Tonga-Lau-Fiji Region. SOPAC Tech. Bull. 8.

Weissel, J.K., 1977. Evolution of the Lau Basin by the growth of small plates. In Talwani, M., and Pitman, W.C. (Eds.), Island Arcs, Deep Sea Trenches and Back-Arc Basins. Am. Geophys. Union, Maurice Ewing Ser., 1:429 436.

Date of initial receipt: 17 February 1993

Date of acceptance: 28 July 1993

Ms 135SR-163 